\title{
HIV-1/2 Antibody and HIV-1 p24 Antigen Measurement
}

National Cancer Institute

\section{Source}

National Cancer Institute. HIV-1/2 Antibody and HIV-1 p24 Antigen Measurement. NCI

Thesaurus. Code C139085.

The determination of the amount of either the HIV-1 or HIV-2 virus and the determination of HIV-1 p24 antigen present in a sample. 